\title{
SCIENCE
}

A WEEKLY JOURNAL DEVOTED TO THE ADVANCEMENT OF SCIENCE, PUBLISHING THE OFFICIAL NOTICES AND PROCEEDINGS OF THE AMERICAN ASSOCIATION FOR THE ADVANCEMENT OF SCIENCE.

Editorial Commiteee : S. Newcomb, Mathematics; R. S. Woodward, Meohanias ; E. C. Pickering, Astronomy ; T. C. Mendenhal, Physics ; R. H. Thurston, Engineering ; Ira Remsen, Chemistry ;

Charles D. Walcotr, Geology ; W. M. Davis, Physiography ; Henry F. Osborn, Paleon-

tology ; W. K. Brooks, C. Hart MrrriaM, Zoology ; S. H. Scuddhr, Entomology ; C. E.

Bessey, N. I. Britron, Botany ; C. S. Minot, Embryology, Histology ; H. P. Bowprtch, Physiology ; J. S. Billings, Hygiene ; William H. Whlch, Pathology ; J. McKnen CatThul, Psychology.

Friday, November 14, 1902.

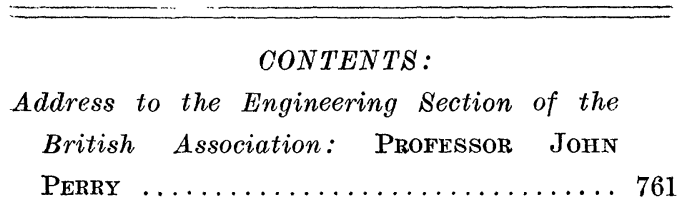

In Memory of John Wesley Powell: Professor

S. P. Langley, Richard Rathbun, Dr. W.

H. Dall, Dr. D. C. Gilman, Dr. Charles

D. Walcott, Commissioner W. T. Harris,

Marcus Baker, Dr. W J McGee....... 782

Scientific Books:-

Heusler's Chemistry of the Terpenes: Pro-

FESSOR EDWARD Kremers............790

Societies and Academies:-

The American Mathematical Society: Pro-

FEssor F. N. Cole............... 791

Discussion and Correspondence:-

The Carnegie Institution: DR. C. H. EIGEN-

MANN. Section H, Anthropology, of the

American Association for the Advancement

of Science: Roland B. Dixon.......... . 792

Shorter Articles:-

Exceptions to Mendel's Law: W. J. SPILL-

MAN ... . . . . . . . . . . . . . . . 794

Notes on Inorganic Chemistry: J. L. H. . . . 796

The Comet B, 1902, and the Mass of Mercury:

Professor Edward C. Prckering....... 797

Scientific Notes and News............. 798

University and Educational News....... 800

MSS. intended for publication and books, etc., intended for review should be sent to the responsible editor, Professor J. McKeen Cattell, Garrison-on-Hudson, N. Y.
ADDRESS TO THE ENGINEERING SECTION OF THE BRITISH ASSOCIATION.*

THis Section has had sixty-six presidents, all different types of engineer. As each has had perfect freedom in choosing the subject for his address, and each has known of the rule $\uparrow$ that presidential addresses are not subject to debate afterwards, and as, being an engineer, he has always been a man of originality, of course he has always chosen a subject outside his own work. An engineer knows that the great inventions, the great suggestions of change in any profession, come from outsiders. Lawyers seem like fish out of water when trying to act as law-makers. The radical change that some of us hope to see before we die in the construction of locomotives will certainly not come from a locomotive superintendent, who cannot imagine a locomotive which is not somehow a lineal descendant of the Rocket.

Hence it is that in almost every case the President of this Section has devoted a small or large part of his address to the subject of the education of engineers. I grant that every president has devoted his life to the education of one engineer-him-

* Given at the Belfast meeting.

$\dagger$ The Committees of Sections $G$ and $L$ have arranged a discussion on 'The Education of Engineers,' this address being regarded as opening the discussion. Thus the rule is not in force this year. 
self-and it is characteristic of engineers that their professional education proceeds throughout the whole of their lives. Perhaps of no other men can this be said so completely. To utilize the forces of nature, to combat nature, to comprehend nature as a child comprehends its mother, this is the pleasure and the pain of the engineer.* A mere scientific man analyzes nature: takes a phenomenon, dissects it into its simpler elements, and investigates these elements separately in his laboratory. The engineer cannot do this. He must take nature as she is, in all her exasperating complexity. He must understand one of nature's problems as a whole. He must have all the knowledge of the scientific man, and ever so much more. He uses the methods of the scientific man, and adds to them methods of his own. The name given to these scientific methods of his own or their results is sometimes ' common-sense,' sometimes ' character,' or ' individuality,' or ' faculty,' or ' business ability,' or ' instinct.' They come to him through a very wide experience of engineering processes, of acquaintance with things and men. No school or college can do more than prepare a young man for this higher engineering education which lasts through life. Without it a man follows only rule of thumb, like a sheep following the bell-wether, or else he lets his inventiveness or love of theory act the tyrant.

When a man has become a great engineer, and he is asked how it happened, what his education has been, how young engineers ought to be trained, as a rule it

* Of all the unskilled labor of the present day, surely that of the modern poet is the most grotesque. How much more powerful and powerless man seems to us now; how much more wonderful is the universe than it was to the ancients! Yet our too learned poets prefer to copy and recopy the sentiments of the ancients rather than try to see the romance which fills the lives of engineers and scientific men with joy. is a question that he is least able to answer, and yet it is a question that he is most ready to answer. He sees that he benefited greatly by overcoming certain difficulties in his life; and forgetting that every boy will have difficulties enough of his own, forgetting that although a few difficulties may be good for discipline, many difficulties may be overwhelming, forgetting also that he himself is a very exceptional man, he insists upon it that those difficulties which were personal to himself ought to be thrown in the path of every boy. It often happens that he is a man who is accustomed to think that early education can only be given through ancient classics. He forgets the dullness, the weariness of his school-days. Whatever pleasure he had in youth-pleasure mainly due to the fact that the average Anglo-Saxon boy invents infinite ways of escaping school drudgery-he somehow connects with the fact that he had to learn classics. Being an exceptional boy, he was not altogether stupefied, and did not altogether lose his natural inclination to know something of his own language; and he is in the habit of thinking that he learned English through Latin, and that ancient classics are the best mediums through which an English boy can study anything.* The cleverest men of our time have been brought up on the classics, and so the engineer who cannot even quote correctly a tag from the Latin grammar, who never knew anything of classic literature, insists upon it that a classical education is essential for all men. He forgets the weary hours he spent getting off Euclid, and the relief it was to escape from the class-room not quite

\footnotetext{
* The very people who talk so much of learning English through Latin neglect in the most curious ways those Platt-Deutsch languages, Dutch and Scandinavian, a knowledge of which is ten times more valuable in the study of what is becoming the speech of the world. And how they do scorn Lowland Scotch!
} 
stupefied, and he advocates the study of pure mathematics and abstract dynamics as absolutely necessary for the training of the mind of every young engineer. I have known the ordinary abominable system of mathematical study to be advocated by engineers who, because they had passed through it themselves, had really got to loathe all kinds of mathematics higher than that of the grocer or housekeeper. They said that mathematics had trained their minds, but they did not need it in their profession. There is no profession which so much requires a man to have the mathematical tool always ready for use on all sorts of problems, the mathematical habit of thought the one most exercised by him; and yet these men insist upon it that they can get all their calculations done for them by mathematicians paid so much a week. If they really thought about what they were saying, it would be an expression of the greatest contempt for all engineering computation and knowledge. $\mathrm{He}$ was pitchforked into works with no knowledge of mathematics, or dynamics, or physics, or chemistry, and, worse still, ignorant of the methods of study which a study of these things would have produced; into works where there was no man whose duty it was to teach an apprentice; and because he, one in a thousand, has been successful, he assures us that this pitchforking process is absolutely necessary for every young engineer. $\mathrm{He}$ forgets that the average boy leaves an English school with no power to think for himself, with a hatred for books, with less than none of the knowledge which might help him to understand what he sees, and he has learned what is called mathematics in such a fashion that he hates the sight of an algebraic expression all of his life after.

I do not want to speak of boys in general. I want only to speak of the boy who may become an engineer, and before speak- ing of his training $I$ want to mention his essential natural qualification-that he really wishes to become an engineer. I take it to be a rule to which there are no exceptions, that no boy ought to enter a profession-or, rather, to continue in a profession-if he does not love it. We all know the young man who thinks of engineering things during office hours and never thinks of them outside office hours. We know how his fond mother talks of her son as an engineer who, with a little more family influence and personal favor, and if there was not so much competition in the profession, would do so well. It is true, family influence may perhaps get such a man a better position, but he will never be an engineer. $\mathrm{He}$ is not fit even to be a hewer of wood and drawer of water to engineers. Love for his profession keeps a man alive to its interests all his time, although, of course, it does not prevent his taking an interest in all sorts of other things as well; but it is only a professional problem that warms him through with enthusiasm. I think we may assume that there never yet was an engineer worth his salt who was not fond of engineering, and so I shall speak only of the education of the young man who is likely to be fond of engineering.

How are we to detect this fondness in a boy? I think that if the general education of all boys were of the rational kind which I shall presently describe, there would be no great difficulty; but as the present academic want of system is likely to continue for some time, it is well to consider things as they are. Mistakes must be made, and the parent who tries during the early years of his offspring to find out by crafty suggestion what line his son is likely to wish to follow, will just as probably do evil by commission as the utterly careless parent is likely to do evil by omission. $\mathrm{He}$ is like the botanical enthusiast 
who digs up plants to see how they are getting on. But in my experience the Anglo-Saxon boy can stand a very great deal of mismanagement without permanent hurt, and it can do no kind of boy any very great harm to try him on engineering for a while. Even R. L. Stevenson, whose father seems to have been very persistent indeed in trying to make an engineer of him against his will, does not seem, to a philistine like myself, to have been really hurt as a literary man through his attendance on Fleeming Jenkins's course at Edinburgh-on the contrary, indeed. It may be prejudice, but I have always felt that there is no great public person of whom I have ever read who would not have benefited by the early training which is suitable for an engineer. I am glad to see that Mr. Wells, whose literary fame, great as it is, is still on the increase, distinguishes the salt of the earth or saviors of society from the degraded, useless, luxurious, pleasure-loving people doomed to the abyss by their having had the training of engineers and by their possessing the engineer's methods of thinking.

It may be that there are some boys of great genius to whom all physical science or application of science is hateful. I have been told that this is so, and if so I still think that only gross mismanagement of a youthful nature can have produced such detestation. For such curious persons engineering. experience is, of course, quite unsuitable. I call them 'curious' because every child's education in very early years is one in the methods of the study of physical science; it is nature's own method of training, which proceeds successfully until it is interfered with by ignorant teachers who check all power of observation, and the natural desire of every boy to find out things for himself. If he asks a question, he is snubbed; if he observes nature as a loving student, he is said to be lazy and a dunce, and is punished as being neglectful of school work. Unprovided with apparatus, he makes experiments in his own way, and he is said to be destructive and full of mischief. But however much we try to make the wild ass submit to bonds and the unicorn to abide by the crib, however bullied and beaten into the average schoolboy type, I cannot imagine any healthy boy suffering afterwards from part of a course of study suitable for engineers, for all such study must follow nature's own system of observation and experiment. Well, whether or not a mistake has been made, I shall assume the boy to be likely to love engineering, and we have to consider how he ought to be prepared for his profession.

I want to say at the outset that I usually care only to speak of the average boy, the boy usually said to be stupid, ninety-five per cent. of all boys. Of the boy said to be exceptionally clever I need not speak much. Even if he is pitchforked into works immediately on leaving a bad school, it will not be long before he chooses his own course of study and follows it, whatever course may have been laid down for him by others. I recollect that when in 1863 I attended an evening class held in the Model School, Belfast, under the Science and Art Department, on practical geometry and mechanical drawing, there was a young man attending it who is now well known as the Right Honorable William J. Pirrie. He had found out for himself that he needed a certain kind of knowledge if he was to escape from mere rule-ofthumb methods in shipbuilding work; it could at that time be obtained nowhere in the north of Ireland except at that class, and of course he attended the class. For forty-two years the Science and Art Department, which has recently doubled its already great efficiency, has been giving chances of this kind to every clever young 
man in the country, from long before any physical science was taught in any English public school.* The one essential thing for the exceptional boy is that he shall find within his reach chances to take advantage of; chances of learning; chances of practice; and, over and above all, chances of meeting great men. It takes me off my subject a little, but I should like here to illustrate this matter from my own personal experience.

I had already been an apprentice for four years at the Lagan Foundry when I entered Queen's College for a course of civil engineering. I suppose that there never was on this earth a college so poorly equipped for a course of engineering study. Even the lecture room-this lecture room in which you are now sitting-was borrowed from the physics professor. There was a narrow passage, ironically called a 'drawing-room,'and this was the only space reserved for engineering in a town whose engineering work was even then very important. There were some theodolites and levels and chains for surveying, but nothing else in the way of apparatus. But there was as professor a man of very great individuality; he acted as president of this Section twenty-eight years ago. I can hardly express my obligations to Professor James Thomson. It was my good fortune to be a pupil both of this great man and of his younger brother, Lord Kelvin, as well as of Dr. Andrews. It is not because these three men were born in Belfast that we here call them great. It is not because Tait, late of Edinburgh, and Purser, now the

* I once stated that my workshop at Clifton College in 1871 was the first school workshop in England. I understand that this is a mistake; there had been a workshop at Rossall for some years. But $I$ believe $I$ am right in saying that my physical laboratory at Clifton was the first school laboratory in England. These ideas were not mine; they were those of the headmaster, now the Bishop of Hereford. president of Section A, were professors at this college that we call them great. All the scientific men of the world are agreed to call these men very great indeed. To come in contact with any of them, even for a little while, as a student, altered forever one's attitude to nature. It was not that they gave us information, knowledge, facts. The syllabuses of their courses of study were nothing like so perfect as that of the smallest German polytechnic. And yet if a youth with a liking for physical science had gone to a German gymnasium to the age of nineteen, and had become a walking encyclopedia on leaving one's polytechnic at the age of twenty-four, the course of that life-study would not have done for him as much good as was done by a month's contact with one of these men. People call it 'personal magnetism,' and think there is something occult about it. In truth, they revealed to the student that he himself was a man, that mere learning was unimportant, that one's own observation of some common phenomenon might lead to important results unknown to the writers of books. They made one begin to think for oneself for the first time. Let me give an example of how the thing worked.

James Thomson was known to me as the son of the author of my best mathematical books, but more particularly as the man who had first used Carnot's principle in combination with the discovery of Joule, and I often wondered why Rankine and Clausius and Kelvin got all the credit of the discovery of the second law of thermodynamics. Men think of this work of his merely as having given the first explanation of regelation of ice and the motion of glaciers. He was known to me as the inventor of the Thomson turbine and centrifugal pump and jet pump. His name was to be found here and there in all my textbooks, always in connection with some thoroughly well-worked-out investigation, as it 
is to be found in all good text-books now; for wherever he left a subject, there that subject has remained until this day; nobody has added to it or found a mistake in it. He was to me a very famous man, and yet he treated me as a fellow-student. One of his early lectures was about flowing water, and he told us of a lot of things he had observed, which I also had observed without much thought; and he showed how these simple observations completely destroyed the value of everything printed in every text-book on the subject of water flowing over gauge-notches, even in the otherwise very perfect Rankine. I felt how stupid I had been in not having drawn these conclusions myself, but in truth till then I had never. ventured for a moment to criticize anything in a book. I have been a cautious critic of all statements in text-books ever since. If any engineer wants to read what is almost the most instructive paper that has ever been written for engineers, let him refer to the latest paper written by James Thomson on this subject.* The reasoning there given was given to me in lectures in this very room in 1868, and had been given to students for many years previous.

Again, soon afterwards, he let me see that although I had often looked at the whirlpool in a basin of water when the central bottom hole is open, and although I had read Edgar Allen Poe's mythical description of the Maëlstrom, I had been very much too careless in my observation. Among other things, Thomson had observed that particles of sand gradually passed along the bottom towards the hole. When he found out the cause of this, it led him at once to several discoveries of great importance. Indeed, the study of this simple observation gave rise to all his work on (1) what occurs at bends of pipes and channels, and why rivers in alluvial plains

*Brit. Assoc. Report, 1876, pp. 243-266. bend more and more; (2) the explanation of the curious phenomena that accompany great forest fires; (3) the complete theory of the great wind circulation of the earth, published in its final form as the Bakerian Lecture of the Royal Society in 1892.

But why go on? He taught me to see that the very commonest phenomenon had still to reveal important secrets to the understanding eye and brain, and that no man is a true student unless he is a discoverer. And so it was with Kelvin and Andrews. Their names were great before the world, and yet they treated one as a fellow-student. Is any expenditure of money too large if we can obtain great men like these for our engineering colleges? Money is wanted for apparatus, and more particularly for men, and we spend what little we have on bricks and mortar!

The memory of a man so absolutely honest as Professor James Thomson was compels me to say here that I was in an exceptionally fit state to benefit by contact with him, for I hungered for scientific information.* I do not think that there

* Some of our most successful graduates went direct to works from the Model School, Belfast, and afterwards attended this College. No school in the British Islands could have given better the sort of general education which I recommend for all boys. English subjects were especially well taught, so that boys became fond of reading all manner of books. There were good classes in freehand and machine drawing, classes in chemistry and physics (at that time I believe that there were no such classes in any English public school), and the teaching of mathematics was good. Some of the masters started classes also under the Science and Art Department. Some of the masters had much individuality, and there was no outside examination to restrain it; there was only encouragement. Evidence has been given before a committee of the London School Board as to the excellence of the teaching at this school forty years ago. Foreign languages were not in the regular curriculum, but they could be studied by boys inclined that way; and in my opinion this is the position that all languages other than English ought to take in any British school. With such preparation a boy was eager and able to understand what went on in engineering works from his first day there. 
was so much benefit for the average student whose early education had almost unfitted him for engineering studies. To work quantitatively with apparatus is good for all students, but it is absolutely necessary for the average student, and, as I said before, there was no apparatus. Also the average student cannot learn from lectures merely, but needs constant tutorial teaching, and the professor had no assistant.

Anybody who wants to know what kind of engineering school there ought to be in such a college as this can see excellent specimens (sometimes several in one town) in Glasgow, Birmingham, Liverpool, London, Manchester, Leeds, Bristol, Nottingham, Edinburgh and other great cities. There the fortunate manufacturers have given many hundreds of thousands of pounds for instruction in applied science (engineering). In America the equipment of such schools is much more thorough, and there are large staffs of teachers, for fortunate Americans have contributed tens of millions of pounds for this kind of assistance to the rising generation. Germany and Switzerland compete with America in such preparation for. supremacy in manufacture and engineering, and nearly every country in the world is more and more recognizing its importance as they see the great inventions of Englishmen like Faraday and Perkin and Hughes and Swan developed almost altogether in those countries which believe in education. Even one hundred thousand pounds would provide Queen's College, Belfast, with the equipment of an engineering school worthy of its traditions and position, and Belfast is a city in which many large business fortunes have been made.

It is interesting to note that the present arrangements of the Royal University of Ireland, with which this college is affiliated, are such that most of the successful graduates in engineering of Queen's University would now be debarred from taking the degree. Even in London University, Latin is not a compulsory subject for degrees in science; Ireland has taken a step backwards towards the Middle Ages at the very time when other countries are stepping forward.

Well-equipped schools of applied science are getting to be numerous, but I am sorry to say that only a few of the men who leave them every year are really likely to become good engineers. The most important reason for this is that the students who enter them come usually from the public schools; they cannot write English; they know nothing of English subjects; they do not care to read anything except the sporting news in the daily papers; they cannot compute; they know nothing of natural science; in fact, they are quite deficient in that kind of general education which every man ought to have.

I am not sure that such ignorant boys would not benefit more by entering works at once than by entering a great engineering school. They cannot follow the college courses of instruction at all, in spite of having passed the entrance examination by cramming. Whereas after a while they do begin to understand what goes on in a workshop; and if they have the true engineer's spirit, their workshop observation will greatly correct the faults due to stupid school work.*

Perhaps I had better state plainly my views as to what gerreral education is best for the average English boy. The public schools of England teach English through Latin, a survival of the time when only special boys were taught at all, and when there was only one language in which people wrote. Now the average boy is also

* When I was young I remember that there were many agricultural colleges in Ireland; they have all but one been failures. Why? Because the entering pupils were not prepared by early education to understand the instruction; this had done as much as possible to unfit them. 
taught Latin, and when he leaves school for the army or any other pursuit open to average boys he cannot write a letter, he cannot construct a grammatical sentence, he cannot describe anything he has seen. The public-school curriculum is always growing, and it is never subtracted from or rearranged. There is one subject which crdinary schoolmasters can teach wellLatin.* The other usual nine subjects have

* Only one subject-Latin-is really educational in our schools. I do not mean that the average boy reads any Latin author after he leaves school, or knows any Latin at all ten years after he leaves school. I do not mean that his Latin helps him even slightly in learning any modern language, for he is always found to be ludicrously ignorant of French or German, even after an elaborate course of instruction in these languages. I do not mean that his Latin helps him in studying English, for he can hardly write a sentence without error. I do not mean that it makes him fond of literature, for of ancient literature or history he never has any knowledge except that Cæsar wrote a book for the third form, and on English literature his mind is a blank. But I do mean that as the ordinary public-school master is really able to give a boy easy mental exercises through the study of Latin, this subject is in quite a different position from that of the others. If any proof of this statement is wanted, it will be found in the published utterances of all sorts of menmilitary officers, business men, lawyers, men of science and others-who, confessedly ignorant of ' the tongues,' get into a state of rapture over their school experiences and the efficiency of Latin as a means of education. All this comes from the fact, which schoolboys are sharp enough to observe, that English schoolmasters can teach Latin well, and they do not take much interest in teaching anything else. It is a power inherited from the Middle Ages, when there really was a simple system of education. I ask for a return to simplicity of system. English (the King's Lnglish; I exclude Johnsonese) is probably the richest, the most complex language, the one most worthy of philologic study; English literature is certainly more valuable than any ancient or modern literature of any one other country, yet admiration for it among learned Englishmen is wonderfully mixed with patronage and even contempt. At present, is there one man who can teich English as Latin is taught by nearly every gradually been added to the curriculum

master of every school? Just imagine that English could be so taught by teachers capable of rising to the level of our literature!

I have often to give advice to parents. I find the average parent exceedingly ignorant of his son's character or inclinations or ability. He pays a schoolmaster handsomely for taking his son off his hands except during holidays. During the holidays, so terrible to a parent, he sees his son as little as possible. One question always asked is: Do you think it better to have 'theoretical' instruction (they always call it by this absurd name) before or after an actual apprenticeship in works? Of course, such a question cannot be answered off-hand. You tell the parent, to his great astonishment, that you must see the boy himself. When at length you see him, the chances are that you will find him to be what the schoolmasters are making of all our average boys. No part of his school work has been a pleasure to him, and, although he has had to work hard at his books, not one of the above three powers is his: power to use books and to write his own language; the language of his nurse, his mother, his mistress that is to be, his enemies and friends; the only language in which he thinks-power to compute and a liking for computation-power to understand a little of natural phenomena. Honestly, I practically never find that such a boy has had any education at all except what he has obtained at home or from his school companions or from his sports. Even his sports are to keep him healthy of body only, and not at all to cultivate his mental powers. Those old games like ' prisoners' base,' which really develop in a wonderful way not only all the muscles of the body, but also the thinking power, are scorned in the public schools. Think now how such a boy is handicapped if we pitchfork him into works where it is nobody's duty to teach him anything, or send him to college, where he cannot understand the lectures. Of course, if he is very eager to be an engineer he will, by hook or by crook, get to understand things. I have met some such men-clever, successful engineers in spite of all sorts of adverse circumstances-but the best of them are willing to admit that they are, and have always been, greatly hurt by the absence of the three powers which I have specified. And if this has been so in the past, when the scientific principles underlying engineering have been simple, how much more so is it now, when every new discovery in physics is producing new branches of engineering! 
for examination purposes; they are taught in water-tight compartments-or, rather, they are only crammed, and not taught at all. Our school system resembles the ordinary type of old-established works where gradual accretion has produced a higgledypiggledy set of shops which one looks at with stupefaction, for it is impossible to get business done in them well and promptly, and yet it seems impossible to start a reform anywhere. What is wanted is an earthquake or a fire-a good fireto destroy the whole works and enable the business to be reconstructed on a consistent and simple plan. And for much the same reason our whole public-school system ought to be 'scrapped.' What we want to see is that a boy of fifteen shall be fond of reading, shall be able to compute, and shall have some knowledge of natural science; or, to put it in another way, that he shall have had mental training in the study of his own language, in the experimental study of mathematics and in the methods of the student of natural science. Such a boy is fit to begin any ordinary profession, and whether he is to enter the Church, or take up medicine or surgery, or become a soldier, every boy ought to have this kind of training. When I have advocated this kind of education in the past I have usually been told that I was thinking only of boys who intended to be engineers; that it was a specialized kind of instruction. But this is very untrue. Let me quote from the recommendations of the 1902 Military Education Committee ('Report,' p. 5) :

"The fifth subject which may be considered as an essential part of a sound general education is experimental science; that is to say, the science of physics and chemistry treated experimentally. As a means of mental training and also viewed as useful knowledge, this may be considered a necessary part of the intellectual equipment of every educated man, and especially so of the officer, whose profession in all its branches is daily becoming more and more dependent on science." When statements of this kind have been made by some of us in the past, nobody has paid much attention; but I beg you to observe that the headmaster of Eton and the headmaster of St. Paul's School are two of the members of the important committee who signed this recommendation, and it is impossible to ignore it. Last year, for the first time, the President of the Royal Society made a statement of much the same kind, only stronger, in his annual address. I am glad to see that the real value of education in physical science is now appreciated; that mere knowledge of scientific facts is known to be unimportant compared with the production of certain habits of thought and action which the methods of scientific study usually produce.

As to English, the committee say: 'They have no hesitation in insisting that a knowledge of English,* as tested by composition, together with an acquaintance with the main facts of the history and geography

* This committee recommends for the Woolwich and Sandhurst candidates a reform that has already been carried out by London University. No dead language is to be compulsory, but unfortunately some language other than English is still to be compulsory. Those boys, of whom there are so many, who dislike and cannot learn another language are still to be labeled 'uneducated.' Must there, then, be national defeat and captivity before our chosen race gives up its false academic gods? We think of education in the most slovenly fashion. The very men who say that utility is of no importance are the men who insist on the usefulness of a knowledge of French or German. They say that a man is illiterate if he knows only English, although he may be familiar with all English literature and with other literatures through translations. The man who has passed certain examinations in his youth and never cares to read anything is said to be ed!1cated. The men of the city of the Violet Crown, were they not educated? And did they know any other than their own language? 
of the British Empire, ought in future to hold the first place in the examination and to be exacted from all candidates.' The italics are mine. It will be noticed that they say nothing about the practical impossibility of obtaining teachers. As to mathematics, the committee say: "It is of almost equal importance that every officer should have a thorough grounding in the elementary part of mathematics. But they think that elementary mechanics and geometrical drawing, which under the name of practical geometry is now often used as an introduction to theoretical instruction, should be added to this part of the examination so as to insure that at this stage of instruction the practical application of mathematics may not be left out of sight." As Sir Hugh Evans would have said, 'It is a very discretion answer-the meaning is good'; but I would that the committee had condemned abstract mathematics for these army candidates altogether.

This report appears in good time. It would be well if committees would sit and take evidence as to the education of men in the other professions entered by our average boys. It is likely that when an authoritative report is prepared on the want of education of clergymen, for example, exactly the same statements will be made in regard to the general education which ought to precede the technical training; but perhaps a reference may be made in the report to the importance of a study of geology and biology, as well as physical science. Think of the clergyman being able to meet his scientific enemies in the gate!

Thanks mainly to the efforts of a British Association Committee, really good teaching of experimental science is now being introduced into all public schools, in spite of most persistent opposition wearing an appearance of friendliness. In consequence, too, of the appointment of a British Asso- ciation Committee last year, at what might be called the psychological moment, a great reform has already begun in the teaching of mathematics. * Even in the regulations for the Oxford Locals for 1903 Euclid is repudiated. It seems probable that at the end of another five years no average boy of fifteen years of age will have been compelled to attempt any abstract reasoning about things ' of which he knows nothing; he will be versed in experimental mathematics, which he may or may not call mensuration; he will use logarithms, and mere multiplication and division will be a joy to him; he will have a working power with algebra and sines and cosines; he will be able to tackle at once any curious new problem which can be solved by squared paper; and he will have no fear of the symbols of the infinitesimal calculus. When I insist that a boy ought to be able to compute, this is the sort of computation that I mean. Five years hence it will be called 'elementary mathematics.' Four years ago it was an unorthodox subject called 'practical mathematics,' but it is establishing itself in every polytechnic and technical college and evening or day science school in the country. Several times I have been informed that on starting an evening class, when plans have been made for a possible attendance of ten or twenty students, the actual attendance has been 200 to 300 . Pupils may come for one or two nights to a class on academic mathematics, but then stay'away forever; a class in practical mathematics maintains its large numbers to the end of the winter.

* Discussion last year and report of committee, published by Macmillan.

† To many men it will seem absurd that a real working knowledge of what is usually called higher mathematics, accompanied by mental training, can be given to the average boy. In the same way it seemed absurd 500 years ago that power to read and write and cipher could be given to everybody. These general beliefs of ours are very wonderful. 
Hitherto the average boy has been taught mathematics and mechanics as if he were going to be a Newton or a Laplace; he learnt nothing and became stupid. I am sorry to say that the teaching of mechanics and mechanical engineering through experiment is comparatively unknown. Cambridge writers and other writers of books on experimental mechanics are unfortunately ignorant of engineering. University courses on engineeringwith one splendid exception, under Professor Ewing at Cambridge-assume that undergraduates are taught their mechanics as a logical development of one or two axioms; whereas in many technical schools under the science and art department apprentices go through a wonderfully good laboratory course in mechanical engineering. We really want to give only a few fundamental ideas about momentum and the transformations of energy and the properties of materials, and to give them from so many points of view that they become part of a student's mental machinery, so that he uses them continually. Instead of giving a hundred labor-saving rules which must be forgotten, we ought to give the one or two ideas which a man's common-sense will enable him to apply to any problem whatsoever and which cannot be forgotten. A boy of good mathematical attainments may build on this experimental knowledge afterwards a superstructure more elaborate than Rankine or Kelvin or Maxwell ever dreamt of as being possible. Every boy will build some superstructure of his own.

I must not dwell any longer on the three essential parts of a good general education which lead to the three powers which all boys of fifteen ought to possess: power to use books and to enjoy reading; power to use mathematics and to enjoy its use; power to study nature sympathetically. English board-school boys who go to even- ing classes in many technical schools after they become apprentices are really obtaining this kind of education. The Scotch Education Board is trying to give it to all boys in primary and secondary schools. It will, I fear, be some time before the sons of well-to-do parents in England have a chance of obtaining it.

When a boy or man of auy age or any kind of experience enters an engineering college and wishes to learn the scientific principles underlying a trade or profession, how ought we to teach him? Here is the reasonable general principle which Professors Ayrton and Armstrong and I have acted upon, and which has so far led us to much success. Whether he comes from a bad or a good school, whether he is an old or young boy or man, approach his intelligence through the knowledge and experience he already possesses. This principle involves that we shall compel the teacher to take the pupil's point of view* rather than the pupil the teacher's; give the student a choice of many directions in which he may study; let lectures be rather to instruct the student how to teach himself than to teach him; show the student how to learn through experiment, and how to use books, and, except for suggestion and help when asked for, leave him greatly to himself. If a teacher understands the principle he will have no difficulty in carrying it out with any class of students. I myself prefer to have students of very different qualifications and experience-in one class, because of the education that each gives to the others. Usually, however, ex-

* Usually it is assumed that there is only one line of study. In mathematics it is assumed that a boy has the knowledge and power and past experience and leisure of an Alexandrian philosopher. In mechanics we assume the boy to be fond of abstract reasoning, that he is a good geometrician who can do the most complex things in geometrical conics, but cannot possibly take in the simplest idea of the calculus. 
cept in evening classes, one has a set of boys coming from much the same kind of school, and, although perhaps differing considerably as to the places they might take in an ordinary examination, really all of much the same average intelligence. Perhaps I had better describe how the principle is carried out in one case-the sons of well-to-do parents such as now leave English schools at about fifteen years of age.

It was for such boys that the courses of instruction at the Finsbury Technical College (the city and guilds of London Institute) were arranged twenty-two years ago. It was attempted to supply that kind of training which ought already to have been given at school, together with so much technical training as might enable a boy at the end of a two years' course to enter any kind of factory where applied science was important, with an observing eye, an understanding brain, and a fairly skillful hand. The system, in so far as it applies to various kinds of mechanical engineering, will be found described in one of a small collection of essays called 'England's Neglect of Science,' pp. 57-67.* I am sure

* The ideas in this address have been put forward many times by Professor Ayrton and myself. See the following, among other publications: 'England's Neglect of Science' (Fisher Unwin); 'Practical Mechanics,' 1881 (Cassell); 'Applied Mechanics,' 1897 (Cassell) ; 'The Steam Engine, etc.,' 1898 (Macmillan); 'The Calculus for Engineers,' 1897 (Arnold); 'Recent Syllabuses and Examination Papers of the Science and Art Department in Subjects I., VII., Vp, and XXII.'; 'Summary of Lectures on Practical Mathematics' (Board of Education); 'The Work of the City and Guilds Central Technical College' (Journal of the Society of. Arts, July 9, 1897) ; inaugural lecture at Finsbury, 1879; address at the Coventry Technical Institute, February, 1898; 'Education of an Electrical Engineer' (Journal of the Society of Telegraph Engineers and of Electricians, September, 1882); presidential address, Institution of Electrical Engineers, January, 1892; 'The Best Education for an Engineer' (Nature), October 12, 1899; address at a drawing-room meeting, March, 1887. that any engineer who reads that description will feel satisfied that it was the very best course imaginable for the average boy of the present time. A boy was taught how he must teach himself after, he entered works. If after two or three years in the works he cared to go for a year or so to one of the greater colleges, or did not so care, it was assumed that he had had such a training as would enable him to choose the course which was really the best for. him.

Old Finsbury students are to be found everywhere in important posts. The experiment has proved so successful that every London polytechnic, every municipal technical school in the country, has adopted the system, and in the present state of our schools I feel sure that all important colleges ought to adopt the Finsbury system. It hardly seems appropriate to apply the word 'system' to what was so plastic and uncrystallized and had nothing to do with any kind of ritual.

The professors were given a free hand at Finsbury, and there were no outside examiners. I need not dwell upon the courses in chemistry and physics; some critics might call the subjects rational chemistry and applied physics; they were as different from all other courses of study in these subjects as the courses on rational mathematics and mechanics differed from all courses elsewhere. The course on mechanics was really one on mechanical engineering. There were workshops in wood and iron, not to teach trades, but rather to teach boys the properties of materials. There were a steam engine and a gas engine, and shafting and gearing of many kinds, and dynamos which advanced students in turn were allowed to look after under competent men. There was no machine which might not be experimented with occasionally. Elementary and advanced courses of lectures were given; there 
was an elaborate system of tutorial classes, where numerical and squared paper exercise work was done; there were classes in experimental plane and solid geometry, including much graphical calculation; boys were taught to make drawing-office drawings in pencil only, and tracings and blue prints, such as would be respected in the workshop, and not the ordinary drawingclass drawings, which cannot be respected anywhere; but the most important part of the training was in the laboratory, in which every student worked, making quantitative experiments. An offer of a 100-ton testing machine for that laboratory was made but refused; the advanced students usually had one opportunity given them of testing with a large machine, but not in their own laboratory. I consider that there is very little educational value in such a machine; the student thinks of the great machine,*

* These great testing-machines, so common in the larger, colleges, seem to have destroyed all idea of scientific experiment. There is so much that the engineer wants to know, and yet laboratory people are persistently and lazily repeating old work suggested and begun by engineers of sixty years ago. For example, men like Fairbairn and Robert Napier would long ago have found out the behavior of materials under combined stresses. We do not even know the condition of strength of iron or steel in a twisted shaft which is also a beam. The theory of strength of a gun or thick tube under hydraulic pressure is no clearer now than it was fifty years ago. The engineer asks for actual information derived from actual trial, and we offer him the 'cauld kail het again' stuff falsely called 'theoretical,' which is found in all the text-books (my own among others). These great colleges of university rank ought to recognize that it is their duty to increase knowledge through the work of their advanced students. The duty is not neglected in the electrical departments of some of the colleges. Perhaps the most instructive reference is to the work done at the Central Technical College of the City and Guilds Institute. at South Kensington, as described by Professor Ayrton in some of the papers already referred to. I cannot imagine a better development of the Finsbury idea in the work of the highest kind of engineering college. and not of the tiny specimen. Junior students loaded wires and beams, or twisted things with very visible weights, and saw exactly what was happening, or they studied vibrating bodies. Many hours were devoted to experiments on a battered, rusty old screw-jack, or some other lifting machine, its efficiency under many kinds of load being determined, and students studied their observations, using squared paper, as intently as if nobody had ever made such experiments before. There was one piece of apparatus, an old fly-wheel bought at a rag-and-bone shop, to which kinetic energy was given by a falling weight, which, I remember, occupied the attention of four white-headed directors of electric companies in 1882 (evening students) for many weeks. A casual first measurement led on to corrections for friction and stiffness of a cord, and much else of a most interesting kind. At the end of six weeks these gentlemen had gained a most thorough computational acquaintance with every important principle of mechanics, a knowledge never, to be forgotten. They had also had a revelation such as comes to the true experimenter-but that is too deep a subject.

Perhaps teachers in the greater colleges will smile in a superior way when they hear of this kind of experimental mechanics being called engineering laboratory work. True, it was elementary mechanics; but is not every principle which every engineer constantly needs called a mere elementary principle of mechanics by superior persons? I find that these elementary principles are very much unknown to men who have passed through elaborate mathematical studies of mechanics. Students found out in that laboratory the worth of formulæ; they gained courage in making calculations from. formulæ, for they had found out the extent of their own ignorance and knowledge. 
I have never approved of elaborate steam engines got up for students' laboratory exercise-work. A professor who had devoted much thought for a year to the construction of such a four-cylinder engine showed a friend how any one or any two or any three or all four cylinders, with or without jacketing, could be used in all sorts of ways. The friend ventured to say: "This engine will be used just once and never after.' The professor was angry, but his friend proved to be right. The professor made experiments with it once himself with a few good students. Unfortunately it was not a sufficiently elaborate investigation for publication. Afterwards he never had time personally to superintend such work; his assistants were busy at other things; his students could not be trusted with the engine by themselves, and to this day it stands in the laboratory a beautiful but useless piece of apparatus. At Finsbury there was an excellent one-cylinder engine with vaporizing condenser. It drove the workshops and electric generators. On a field-day it drove an electric generator only, and perhaps thirty students made measurements. Each of them had already acted as stoker and engine-driver, as oiler and tester of the machinery, lighting fires, taking indicator diagrams, weighing coals, opening and closing cocks from seven in the morning to ten at night, so that everything was well known to him. They maintained three different steady loads for trials of three hours each. They divided into groups, one from each group ceasing to take a particular kind of observation every ten minutes and removing to another job. All watches were made to agree, and each student noted the time of each observation. These observations were: Taking indicator diagrams, checking the speed indicator, taking temperature of feed-water, quantity of feed by meter (the meter had been care- fully checked by gauge-notch, and every other instrument used by us had been tested weeks before), taking the actual horsepower passing through a dynamometer coupling on the shaft, taking boiler and valve-chest pressures and vacuum pressures on the roof and in the engine-room, weighing coals (the calorific value had already been tested), taking the horse-power given out by the dynamo, counting the electric lamps in use, and so on. Each student was well prepared beforehand. During the next week he reduced his own observations, and some of the results were gathered on one great table. One lesson that this taught could never be forgotten-how the energy of one pound of coal was disposed of. So much up the chimney or by radiation from boiler or steam-jacket and pipes; in condensation in the cylinder; to the condenser; in engine friction; in shaft friction, etc. I cannot imagine a more important lesson to a young engineer than this one taught through a common working engine. The students had the same sort of experience with a gas engine. I need hardly say how important it was that the professor himself should take charge of the whole work leading up to, during, and after such a field-day.

The difficulty about all laboratory exercise work worth the name is that of finding demonstrators and assistants who are wise and energetic. Through foolishness and laziness the most beautiful system becomes an unmeaning routine, and the more smoothly it works the less educational it is. In England just now the curse of all education is the small amount of money available for the wages of teachers-just enough to attract mediocre men. I have been told, and I can easily imagine, that such men have one talent over-developed, the talent for making their job softer and softer, until at length they just sit at a table, maintaining discipline merely by 
their presence, answering the questions of such students as are earnest enough to come and worry them. In such cases it is absolutely necessary to periodically upset their clockwork arrangements. After such an artificial earthquake one might be reminded of what occurred at the pool of Bethesda, whose waters had their healing property restored when the angel came down and troubled them. But for a permanently good arrangement there ought to be very much higher wages all around in the teaching profession.

No kind of engineering has developed so rapidly as the electrical. Why, it was at the meeting here in Belfast twentyeight years ago (I remember, for I was a secretary of Section A that year, and took the machine to pieces afterwards in Lord Kelvin's laboratory) that there was exhibited for the first time' in these islands a small Gramme machine. This handmaid of all kinds of engineering is now so important that every young engineer may be called uneducated who has not had a training in that kind of mechanical engineering which is called electrical engineering. Professor Ayrton's laboratory at Finsbury is the model copied by every other electrical engineering laboratory in the world. He and I had the same notions; we had both been students of Lord Kelvin; we had worked together in Japan since 1875; but whereas I was trying to make my system of teaching mechanical engineering replace an existing system, or want of system, there was no existing system for his to replace. Thus it will be found that in every electrical engineering laboratory the elementary principles are made part of a pupil's mental machinery by many quantitative experiments, and nobody suggests that it is mere elementary physics which is being taught-a suggestion often enough made about the work in my mechanical laboratory. When students know these elementary principles well, they can apply their. mathematics to the subject. As they advance in knowledge they are allowed to find out by their own experiments how their simple theories must be made more complex in real machines. Their study may be very complete, but, however much mathematics and graphical calculation may come in, their designs of electrical machinery are really based upon the knowledge acquired by them in the electrical and mechanical laboratories.

The electrical engineer has an enormous advantage over other engineers; everything lends itself to exact calculation, and a completed machine or any of its parts may be submitted to the most searching electrical and magnetic tests, since these tests, unlike those applied by other engineers, do not destroy the body tested. But for this very reason, as a finished product, the electrical engineer cannot have that training in the exercise of his judgment in actual practical work after he leaves a college that some other engineers must have. In tunneling, earthwork, and building, in making railways and canals, the engineer is supremely dependent on the natural conditions provided for him, and these conditions are never twice the same. There are no simple laws known to us about the way in which sea and river currents will act upon sand and gravel, and engineers who have had to do with such problems are continually appealing to nature, continually making observations and bringing to bear upon their work all the knowledge and habits of thought that all their past experience has given them. I do not know that there is any job which a good teacher would have greater pleasure in undertaking than the arrangement of a laboratory in which students might study for themselves such problems as come before railway, canal, river, harbor and coast-protection engineers; there is no such laboratory 
in existence at the present time, and in any case it could only be of use in the way of mere suggestion to an engineer who had already a good knowledge of his profession.

It was a curious illustration of mental inertia that the usual engineering visitor, even if he was a professor of engineering, always seemed to suppose that the work done at Finsbury was the same as that done in all the great engineering colleges. As a matter of fact no subject was taught there in the same manner as it was taught elsewhere.*

Most of the students were preparing for electrical or mechanical engineering, and therefore we thought it important that nearly every professor or demonstrator or teacher should be an engineer. I know of nothing worse than that an engineering student should be taught mathematics or physics or chemistry by men who are ignorant of engineering, and yet nothing is more common in colleges of applied science. $\uparrow$ The usual courses are only suitable for men who are preparing to be mere mathematicians, or mere physicists, or mere chemists. Each subject is taken up in a stereotyped way, and it is thought quite natural that in one year a student shall have only a most elementary knowledge of what is to the teacher such a great subject. 'The young engineer never reaches the advanced parts which might be of use to him; he is not sufficiently. grounded in general principles; his whole course is only a preliminary course to a more advanced one

\footnotetext{
* It is really ludicrous to see how all preachers on technical education are supposed by non-thinking people to hold the same doctrine. The people asking for reform in education differ from one another more than Erasmus and Luther and John of Leyden and Knipperdoling.

$\dagger$ At the most important colleges the usual professor or tutor is often ignorant of all subjects except his own, and he generally seems rather proud of this; but surely in such a case a man cannot be said to know even his own subject.
}

which there is no intention of allowing him to pursue, and, not being quite a fool, he soon sees how useless the thing is to him. The professor of chemistry ought to know that until a young engineer can calculate exactly by means of a principle, that principle is really unknown to him. For example, take the equation supposed to be known so well,

$$
2 \mathrm{H}_{2}+\mathrm{O}_{2}=2 \mathrm{H}_{2} \mathrm{O} \text {. }
$$

It is never understood by the ordinary elementary chemical student who writes it down so readily. Every one of the six cunning ways in which that equation conveys information ought to be as familiar to the young engineer as they are, or ought to be, to the most specialized chemist. Without this he cannot compute in connection with combustion in gas and oil engines and in furnaces. But I have no time to dwell on the importance of this kind of exact knowledge in the education of an engineer.

Mathematics and physics and chemistry are usually taught in water-tight compartments, as if they had no connection with one another. In an engineering college this is particularly bad. Every subject ought to be taught through illustrations from the professional work in which a student is to be engaged. An engineer has been wasting his time if he is able to answer the questions of an ordinary examination paper in chemistry or pure mathematics. The usual mathematical teacher thinks most of those very parts of mathematics which to an ordinary man who wants to use mathematics are quite valueless, and those parts which would be altogether useful and easy enough to understand he never reaches; and as I have said, so it is also in chemistry. Luckily, the physics professor has usually some small knowledge of engineering; at all events he respects it. When the pure mathe- 
matician is compelled to leave the logical sequence which he loves to teach mechanics, he is apt scornfully to do what gives him least trouble; namely, to give as 'mechanics' that disguised pure mathematics which forms ninety per cent. of the pretence of theory to be found in so many French and German books on machinery. As pure mathematical exercise work it is even meaner than the stupid exercises in school algebras; as pretended engineering it does much harm because a student does not find out its futility until after he has gone through it, and his enthusiasm for mathematics applied to engineering problems is permanently hurt. But how is a poor mathematical professcr who dislikes engineering, feeling like Pegasus harnessed to a common wagon-how is he to distinguish good from evil? He fails to see how worthless are some of the books on 'theoretical mechanics' written by mathematical coaches to enable students to pass examinations. An engineer teaching mathematics would avoid all futilities; he would base his reasoning on that experimental knowledge already possessed by a student; he would know that the finished engineer cannot hope to remember anything except a few general principles, but that he ought to be able to apply these, clumsily or not, to the solution of any problem whatsoever. of course he would encourage some of his pupils to take up Thomson and Tait or Rayleigh's 'Sound,' or some other classical treatise as an advanced study.*

* One sometimes finds a good mathematician brought up on academic lines taking to engineering problems. But he is usually stale and unwilling to go thoroughly into these practical matters, and what he publishes is particularly harmful, because it has such an honest appearance. When we do get, once in forty years, a mathematician (Osborne Reynolds or Dr. Hopkinson) who has common-sense notions about engineering things, or a fairly good engineer (Rankine or James Thomson) who has a common-sense command
Not only do I think that every teacher in an engineering college ought to have some acquaintance with engineering, but it seems to me equally important to allow a professor of engineering, who ought, above all things, to be a practical engineer, to keep in touch with his profession. A man who is not competing with other engineers in practical work very quickly becomes antiquated in his knowledge: the designing work in his drawing-office is altogether out of date; he lectures about old difficulties which are troubles no longer; his pupils have no enthusiasm in their work because it is merely academic and lifeless; even when he is a man distinguished for important work in the past his students have that kind of disrespect for his teaching which makes it useless to them. If there is fear that too much well-paid professional work will prevent efficiency in teaching, there is no great difficulty in applying a remedy.

One most important fact to be borne in mind is that efficient teachers cannot be obtained at such poor salaries as are now given. An efficient laborer is worthy of his hire; an inefficient laborer is not worthy of any hire, however small. Again, there is a necessity for three times as many teachers as are usually provided in England. The average man is in future to be really educated. This means very much more personal attention, and from thoughtful teachers. Is England prepared to face the problem of technical education in the only way which can lead to success, prepared to pay a proper price for the real

of mathematics, we have men who receive the greatest admiration from the engineering profession, and yet it seems to me that quite half of all the students leaving our technical colleges ought to be able to exercise these combined powers if mathematics were sensibly taught in school and college. We certainly have had enough of good mathematicians meddling with engineering theory and of engineers with no mathematics wasting their time in trying to add to our knowledge. 
article? If not, she must be prepared to see the average man remaining uneducated.

Advocacy of teaching of the kind that was given at Finsbury is often met by the opposition not only of pure mathematicians and academic teachers, but I am sorry to say also of engineers. The average engineer not merely looks askance at, he is really opposed to, the college training of engineers, and I think, on the whole, that he has much justification for his views. University degrees in engineering science are often conferred upon students who follow an academic course, in which they learn little except how to pass examinations. The graduate of to-day, even, does not often possess the three powers to which I have referred. He is not fond of reading, and therefore he has no imagination, and the idea of an engineer without imagination is as absurd as Teufelsdröch's notion of a cast-iron king. He cannot really compute, in spite of all his mathematics, and he is absurdly innocent of the methods of the true student of nature. This kind of labeled scientific engineer, is being manufactured now in bulk because there is a money value attached to a degree. $\mathrm{He}$ is not an engineer in any sense of the word, and does not care for engineering, but he sometimes gets employment in technical colleges. He is said to teach when he is really only impressing upon deluded pupils the importance of formulæ, and that whatever is printed in books must be true. The real young engineer, caught in this eddy, will no doubt find his way out of it, for the healthy experience of the workshop will bring back his common-sense. For the average pupil of such graduates there is no help. If he enters works, he knows but little more than if he had gone direct from school. He is still without the three qualifications which are absolutely necessary for a young engineer. $\mathrm{He}$ is fairly certain to be a nuisance in the works and to try an- other profession at the end of his pupilage. But if it is his father's business he can make a show of knowing something about it, and he is usually called an engineer.

Standardization in an industry usually means easier and cheaper and better manufacture, and a certain amount of it must be good even in engineering, but when we see a great deal of it we know that in that industry the true engineer is disliked. I consider that in the scholastic industry there has been far too much standardization. Gymnasien and polytechnic systems are standardized in Germany, and there is a tendency to import them into England; but in my opinion we are very far indeed from knowing any system which deserves to be standardized, and the worst we can copy is what we find now in Germany and Switzerland. What we must strive for is the discovery of a British system suiting the British boy and man. The English boy may be called stupid so often that he actually believes himself to be stupid; but of one thing we may be sure, he will find in some way or other an escape from the stupefying kind of school work to which the German boy submits. And if it were possible to make the average English boy of nineteen pass such a silly school-leaving examination as the German boy,* and to pass through a polytechnic, I am quite sure that there would be little employment among common-sense English engineers for such a manufactured article. But is it possible that British boys could be manufac-

* The following is, I understand, a stock question at certain gymnasien: 'Write out all the trigonometrical formulæ you know.' I asked my young informant, 'Well, how many did you write?' 'Sixty-two' was the answer. This young man informed me that a boy could not pass this examination unless he knew 'all algebra and all trigonometry and all science.' Strassburg geese used to be fed in France; now they are fed in Germany. German education seems to be like smothering a fire with too much fuel, or wet slack which has the appearance of fuel. 
tured into such obedient academic machines, without initiative or invention or individuality, by teachers who are none of them engineers? No, we must have a British system of education. We cannot go on much longer as we have done in the past without engineering education, and, furthermore, it must be such as to commend itself to employers. Of my Finsbury students I think I may say that not one failed to get into works on a two or three years' engagement, receiving some very small wage from the beginning, and without paying a premium. To obtain such employment was obviously one test of fitness to be an engineer, because experienced men thought it impossible. One test of the system was the greater ease with which new men obtained employment in shops which had already taken some of our students. It is certainly very difficult to convince an employer that a college man will not be a nuisance in the shops. In Germany and France, and to a less extent in America, there is among employers a belief in the value of technical education. In England there is still complete unbelief. I have known the subscribers of money to a large technical college in England (the members of its governing board) to laugh, all of them, at the idea that the college could be of any possible benefit to the industries of the town. They subscribed because just then there was a craze for technical education due to a recent panic. They were ignorant masters of works (sons of the men who had created the works), ignorant administrators of the college affairs, and ignorant crities of their mismanaged college. I feel sure that if the true meaning of technical education were understood, it would commend itself to Englishmen. Technical education is an education in the scientific and artistic principles which govern the ordinary operations in any industry. It is neither a science, nor an art, nor the teaching of a handicraft. It is that without which a master is an unskilled master; a foreman an unskilled foreman; a workman an unskilled workman; and a clerk or farmer an unskilled clerk or farmer. The cry for technical education is simply a protest against the existence of unskilled labor of all kinds.*

To have any good general system the employers must cooperate. Much of the training is workshop practice, and it cannot be too often said that this is not to be given in any college. The workshop in a college serves a quite different purposé. Now how may the practice best be given? I must say that I like the Finsbury plan

* I have pointed out how natural it is that business men should feel somewhat antagonistic to college training. Poorly paid, unpractical teachers, with no ideas of their own, have in the past taught in the very stupidest way. They have called themselves 'scientific' and 'theoretical' till these words stink in the nostrils of an engineer. When $I$ was an apprentice, and no doubt it is much the same now, if an apprentice was a poor workman with his hands he often took to some kind of study which he called the science of his trade. And in this way a pawkiness for science got to be the sign of a bad workman. But if workmen were so taught at school that they all really knew a little physical science, it would no longer be laughed at. When a civil or electrical engineer is unsuccessful because he has no business habits, he takes to calculation and the reading of so-called scientific books, because it is very easy to get up a reputation for science. The man is a bad engineer in spite of his science, but people get to think that he is an unpractical man because of his scientific knowledge. I do believe that the unbelief in technical education so very general has this kind of illogical foundation. Four hundred years ago if a layman could read or write he was probably a useless person who, because he could not do well otherwise, took to learning. What a man learnt was clumsily learnt; usually he learnt little with great labor and made no use of it; therefore reading and writing seemed useless. Now that everybody is compelled to read and write, it is not a usual thing to say that it hurts a man to have these powers. 
very much indeed, but there are others. When I attended this college in winter I was allowed to work in the Lagan Foundry in summer. In Japan the advanced students did the same thing; they had their winter courses at the college, and the summer was spent in the large government workshops; the system worked very well indeed.* In Germany recently the great unions of manufacturers made facilities for giving a year of real factory work to the polytechnic students, but it seems to me that these men are much too old for entrance to works, and, besides, a year is too short a time if the finished product is to call itself a real engineer. Possibly the British solution may be quite different from any of these. A boy may enter works at fourteen on leaving a primary school or not later than sixteen on leaving a secondary school. In either case he must have the three powers to which I have already referred so often. It will be recognized as the duty of the owners of works to provide, either in one large works or near several works, in a well-equipped school following the Finsbury principle, all that training in the principles underlying the trade or profession which is necessary for the engineer.

No right-thinking engineer has been scared by the newspaper writers who tell us of our loss of supremacy in manufacture, but I think that every engineer sees the necessity for reform in many of our ways, and especially in this of education. People talk of the good done to our. workmen's ideas by the strike of two years ago; it is to be hoped that the employers' ideas were also expanded by their having' been forced to travel and to see that their shops were quite out of date. $\dagger$ In fact, we have

* It was the idea of Principal Henry Dyer.

$\uparrow$ Not only is there an enormous improvement in the use of limit-gauges and checking and tools, and the careful calculation of rates of doing work all got to see that there is far too much unskilled labor among workmen and foremen and managers, and especially in owners. There may be some kinds of manufacture so standardized that everything goes like a wound-up clock, and no thought is needed anywhere; but certainly it is not in any branch of engineering. Many engineering things may be standardized, but not the engineer himself. Millions of money may build up trusts, but they will be wasted if the unskilled labor of mere clerks is expected to take the place of the thoughtful skilled labor of owners and managers. I go further, and say that no perfection in labor-saving tools will enable you to do without the skilled, educated, thoughtful, honest, faithful workman with brains. I laugh at the idea that any country has better workmen than ours, and I consider education of our workmen* to be the corner-stone of prosperity in all engineering manufacture. It is from him in countless ways that all hints leading to great inventions come. New countries like America and Germany have their chance just now ; they are starting, without

by various tools and general shop arrangement, but attention is being paid to the comfort of workmen. There are basins and towels, and hot and cold water for them to wash in. In the old days it would have been called faddy philanthropy. Now, owners of works who scorn all softness of heart provide perfect water-closets for their men; their workshops are kept at a uniform temperature; the evil effect of a bad draught in producing colds, or a bad light in hurting the eyes, is carefully considered. In some of these works it is actually possible for a workman or a member of his family to get a luxurious hot bath for a penny. Will this really pay? Some clever hard-headed men of my acquaintance say they already see that it does pay very well indeed.

* The old apprenticeship system of training men has broken down and this is the cause of most of our industrial troubles. An apprenticeship system suited to modern conditions is described fully on pages 68-88 of 'England's Neglect of Science.' 
having to 'scrap' any old machinery or old ideas, with the latest machinery and the latest ideas. For them also the time will come when their machines will be getting out-of-date and the cost of 'scrapping' will loom large in their eyes. In the meantime they have taught us lessons, and this greatest of all lessons - that unless we look ahead with much judgment, unless we take reasonable precautions, unless we pay some regard to the fact that the cleverest people in several nations are hungry for our trade and jealous of our supremacy, we may for a time lose a little of that supremacy. In the last twenty-three years I have written a good deal about the harm done to England by the general dislike that there is among all classes for any kind of education. I do not say that this dislike is greater than it used to be in England; I complain that it is about as great. But I have never spoken of the decadence of England. It is only that we have been too confident that those manufactures and that commerce and that skill in engineering, for which Napoleon sneered at us, would remain with us forever. Many writers have long been pointing out the consequences of neglecting education; prophesying those very losses of trade, that very failure of engineers to keep their houses in order, which now alarms all newspaper writers. Panics are ridiculous, but there is nothing ridiculous in showing that we can take a hint. We have had a very strong hint given us that we cannot forever go on with absolutely no education in the scientific principles which underlie all engineering. There is another important thing to remember. Should foreigners get the notion that we are decaying, we shall no longer have our industries kept up by an influx of clever Uitlanders, and we are much too much in the habit of forgetting what we owe to foreigners, Fleming and German, Hollander, Huguenot and $\mathrm{He}$ - brew, for the development of our natural resources. Think of how much we sometimes owe to one foreigner like the late Sir William Siemens.

But I am going too far; there is after all not so very much of the foolishness of Ishbosheth among us, and I cannot help but feel hopeful as I think lovingly of what British engineers have done in the past. We who meet here have lived through the pioneering time of mechanical and electrical and various other kinds of engineering. Our days and nights have been delightful because we have had the feeling that we also were helping in the creation of a quite new thing never before known. It may be that our successors will have a better time, will see a more rapid development of some other applications of science. Who knows? In every laboratory of the world men are discovering more and móre of nature's secrets. The laboratory experiment of to-day gives rise to the engineering achievement of to-morrow. But I do say that, however great may be the growth of engineering, there can never be a time in the future history of the world, as there has never before been a time, when men will have more satisfaction in the growth of their profession than engineers have had during the reign of Queen Victoria.

And now I want to call your attention to a new phenomenon. Over and over. again has attention been called to the fact that the engineer has created what is called 'modern civilization,' has given luxuries of all kinds to the poorest people, has provided engines to do all the slave labor of the world, has given leisure and freedom from drudgery, and chances of refinement and high thought and high emotion to thousands instead of units. But it is doing things more striking still. Probably the most important of all things is that the yoke of superstitions of all kinds on the 
souls of men should be lifted. The study of natural science is alone able to do this, but education through natural science for the great mass of the people, even for the select few called the distinguished men of the country, has been quite impossible till recently. I say that it is to engineers that the world owes the possibility of this new study becoming general. In our country nearly all discoveries come from below. The leaders of science, the inventors, receive from a thousand obscure sources the germs of their great discoveries and inventions. When every unit of the population is familiar with scientific ideas our leaders will not only be more numerous, but they will be individually greater. And it is we, and not the schoolmasters, who are familiarizing the people with a better knowledge of nature. When men can hardly take a step without seeing steam engines and electro-motors and telegraphs and telephones and steamships, with drainage and water works, with railways and electric tramways and motor-cars; when every shop-window is filled with the products of engineering enterprise, it is getting rather difficult for people to have any belief in evil spirits and witcheraft.

All the heart-breaking preaching of enthusiasts in education would produce very little effect upon an old society like that of England if it were not for the engineer. $\mathrm{He}$ has produced peace. $\mathrm{He}$ is turning the brown desert lands of the earth into green pastures. $\mathrm{He}$ is producing that intense competition among nations which compels education. If England has always been the last to begin reform, she has always been the most thorough and steadfast of the nations on any reform when once she has started on it. Education, pedagogy, is a progressive science; and who am I that I should say that the system of education advocated by me is that which will be found best for England? In school education of the average boy or man England has as yet had practically no experience, for she has given no real thought to it. Yet when she does, I feel that although the Finsbury scheme for engineers may need great improvement, it contains the germ of that system which must be adopted by a race which has always learned through trial and error, which has been led less by abstract principles or abstract methods of reasoning than any race known in history.

JoHn Perry.

\section{IN MEMORY OF JOHN WESLEY POWELL.}

To THE Editor of ScIence:

Dear Sir:

It has for many years been the custom at the Smithsonian Institution to hold a meeting of the friends and associates of a member of the staff who shall have passed away, not by the way of portraying his life and services, but rather as an immediate mark of respect. These proceedings have usually been private, but I have thought that the minutes of the meeting held on the day of the funeral of Major Powell, so long and so widely known in official and scientific circles and an editor of your journal, should be made a matter of public record, and I am transmitting them to you in the hope that you may find a place for them in Scrence. They are words of grief and affection and were not intended as a memorial of the life and work of Major Powell, which I am expecting his friends and associates here in Washington and elsewhere to portray later on. Quite before Major Powell's work as' an administrator and a scientific man, before his very great achievements as an explorer, before the influence he had in molding the work and, indeed, the lives, of many scores of young men who came under his influence, there was the man himself, one to be loved and admired, no matter what his walk in life had been. During years of association he had won such an affection from me, and it is a comforting thought, which I cherish, that this affection was returned.

Very respectfully yours,

S. P. LANGLey, Secretary. 